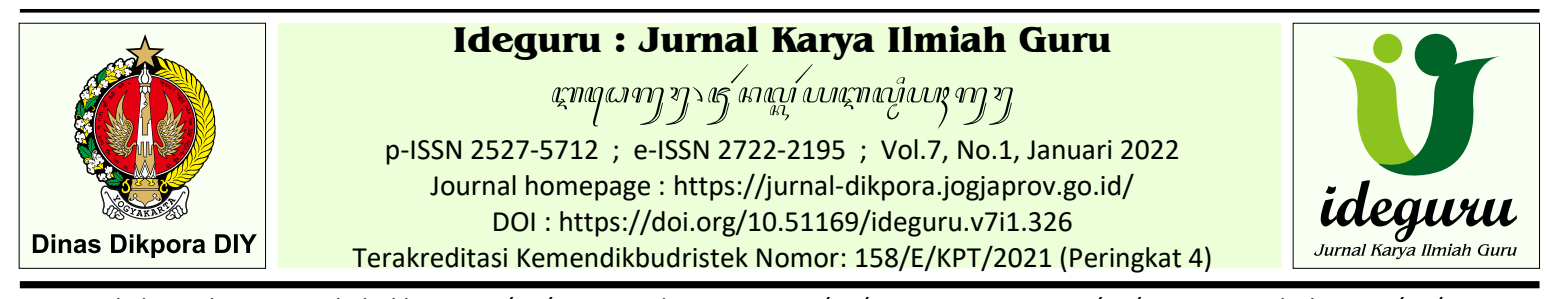

Artikel Penelitian - Naskah dikirim: 23/11/2021 - Selesai revisi: 14/12/2021 - Disetujui: 15/12/2021 - Diterbitkan: 01/01/2022

\title{
Penerapan Blended Learning untuk Meningkatkan Minat dan Prestasi Belajar pada Pembelajaran Matematika
}

\author{
Anggraeni Ratna Winanti \\ SMA Negeri 1 Bambanglipuro, Bantul, Daerah Istimewa Yogyakarta, Indonesia \\ anggerantar@gmail.com
}

\begin{abstract}
Abstrak: Penelitian tindakan kelas ini bertujuan untuk meningkatkan minat dan prestasi belajar siswa pada pembelajaran matematika melalui blended learning. Penelitian dilakukan dalam dua siklus dengan tiap siklusnya menggunakan empat komponen yakni planning, act, observing, dan reflecting. Subjek pada penelitian ini adalah siswa kelas XI IPS 2 SMA Negeri 1 Bambanglipuro Tahun Pelajaran 2020/2021. Teknik pengumpulan data yang digunakan pada penelitian ini adalah lembar observasi guru, lembar observasi siswa, instrumen angket minat belajar siswa dan instrumen tes prestasi belajar siswa. Analisis data pada penelitian ini mencakup penyajian data dan penarikan kesimpulan. Hasil penelitian menunjukkan bahwa; 1) penggunaan blended learning mampu meningkatkan minat belajar siswa dilihat dari data pada siklus II telah mencapai indikator keberhasilan yakni sebesar 33,33\% siswa memiliki minat sangat tinggi, 66,67\% siswa memiliki minat tinggi dalam kelas tersebut; 2) penggunaan blended learning mampu meningkatkan prestasi belajar siswa hal ini dapat dilihat dari data pada siklus II telah mencapai indikator keberhasilan sebesar 76,67\% yakni 23 siswa telah tuntas dari 30 siswa di dalam kelasnya, dan 3) hasil observasi pelaksanaan blended learning pada siklus II telah mencapai indikator keberhasilan dengan persentase sebesar 96,67\%. Dari keseluruhan hasil penelitian, blended learning disimpulkan mampu meningkatkan minat dan prestasi belajar siswa pada pembelajaran matematika.
\end{abstract}

Kata kunci: minat; prestasi belajar; blended learning.

\section{Application of Blended Learning to Increase Interest and Learning Achievement in Mathematics Learning}

\begin{abstract}
This classroom action research aims to improve student's interest and learning achievement in mathematics learning through the blended learning model. The research conducted in two cycles with each cycle using four components, consist of planning, acting, observing, and reflecting. The subjects in this study were students of class XI IPS 2 SMA Negeri 1 Bambanglipuro in 2020/2021 academic year. Data collection techniques used in this study were teacher observation sheets, student observation sheets, student interest questionnaire instruments, and student achievement test instruments. Data analysis in this study includes presenting data and drawing conclusions. The results showed that; 1) the implementation of the blended learning in cycle II had reached the success indicator with a percentage of 95.24\%; 1) the use of the blended learning model is able to increase students' interest, seen from the data in cycle II, it has achieved success indicators of $76.67 \%$ of students are in the high category and $33.33 \%$ of students are in the very high category in the class, and 2) the use of the blended learning is able to improve student achievement. This can be seen from the data in the second cycle that has achieved a success indicator of $76.67 \%$, that is, 23 students are considered completely out of 30 students in their class. 3) the results of the observations on the implementation of the blended learning in cycle II had reached the success indicator with a percentage of $96.67 \%$. Based on the research results, blended learning can improve improve student's interest and learning achievement in mathematics learning.
\end{abstract}

Keywords: interest; learning achievement; blended learning.

\section{Pendahuluan}

Kemajuan zaman begitupun juga perkembangan peradaban manusia tidak dapat dipisahkan dari unsur matematika. Matematika banyak dipergunakan pada berbagai kajian ilmu seperti ilmu kedokteran, pengetahuan alam, sosial, juga dalam sektor perdagangan (NCTM, 2000: 66). Selain itu matematika disebutkan memiliki peran dalm kehidupan yang sangat penting (Skemp, 1971: 132). 
Sebagai mata pelajaran wajib yang diajarkan sejak tingkat dasar sampai dengan tingkat menengah atas, matematika dijadikan parameter di dalam pengukuran tingkat berpikir seseorang dan tingkat intelegensi siswa. Pada Permendikbud RI Nomor 59 tahun 2014 disebutkan bahwa matematika sekolah berbeda dengan mata pelajaran yang lain sebab mempunyai: (1) karakteristik penyajian; (2) karakteristik pola pikir; (3) karakteristik keterbatasan semesta; dan (4) karakteristik tingkat keabstrakan tertentu. Karakteristik yang dimiliki oleh matematika sekolah penting untuk digunakan dalam pertimbangan guru pada saat melaksanakan pembelajaran supaya tujuan pembelajaran tercapai. Tujuan dari sebuah pembelajaran akan dapat dicapai apabila kegiatan pembelajaran matematika dapat dilangsungkan secara efektif.

Pembelajaran yang ideal oleh Dick, Carey, \& Carey (2014: 2) merupakan proses sistematik yang mana tiap-tiap komponen seperti siswa, guru, bahan pembelajaran, dan lingkungan belajar berperan mensukseskan pembelajaran. Lebih lanjut Herman Hudojo (1988: 6) menyebutkan pembelajaran matematika merupakan interaksi secara dua arah antara siswa dengan guru yang interaksinya saling mempengaruhi hasil pembelajaran matematika. Kegiatan pembelajaran matematika yang dapat berjalan efektif akan mampu menumbuhkan pemahaman mengenai materi yang sedang dipelajari oleh siswa (NCTM, 2000: 16). Artinya bahwa proses kegiatan pembelajaran yang efektif akan berpengaruh terhadap materi yang sedang dipelajari oleh siswa.

Wabah Corona Virus yang menghantam penduduk dunia memberikan tantangan tersendiri pada bidang pendidikan. Social distancing merupakan kebijakan yang diterapkan oleh pemerintah sebagai upaya membatasi interaksi agar masyarakat terhindar dari penularan Corona Virus Disease. Pandemi Corona Virus Disease ini menyebabkan beberapa perubahan kebijakan negara salah satunya adalah perubahan dalam penyelenggaraan pendidikan.

Pembelajaran daring online merupakan salah satu solusi dari pelaksanaan pembelajaran dalam masa pandemi. Metode pembelajaran daring online memang tidak seefektif pembelajaran tatap muka atau pembelajaran luring. Siswa mempelajari materi pembelajaran secara mandiri dari rumah tanpa memperoleh penjelasan dari guru. Permasalahan kesulitan dari siswa dalam mempelajari materi pembelajaran matematika yang dilakukan secara daring online diduga disebabkan oleh keterbatasan interaksi guru dengan siswa. Slameto (2012: 76) menyatakan bahwa pendekatan dan strategi mengajar mempengaruhi keberhasilan sebuah pembelajaran matematika.

Popham (2011: 179) menyatakan ranah afektif menentukan keberhasilan belajar siswa. Mitchell (1997: 22) menyatakan bahwa minat dari siswa terhadap pembelajaran matematika merupakan ranah afektif sebagai faktor penting yang dapat menentukan prestasi belajar siswa pada matematika. Dai \& Sternberg (2004: 94-95) menyatakan bahwa seseorang yang memiliki minat akan terfokus pada perhatian, keterlibatan, atau keduanya dengan kemampuan pada suatu konten tertentu.

Senada dengan hal tersebut, Nitko \& Brookhart (2007: 448) menjelaskan minat didefinisikan sebagai sebuah pilihan melakukan aktivitas tertentu pada saat tanpa tekanan dari pihak manapun. Sedangkan Elliot, et al. (2000: 345) menyatakan minat sama halnya serta terhubung dengan rasa ingin tahu, minat juga diartikan sebagai sebuah karakteristik perasaan abadi dari hubungan seseorang antara kegiatan khusus atau objek. Dengan demikian aspek minat belajar yang dimiliki oleh siswa merupakan salah satu faktor penting yang akan menentukan prestasi belajarnya.

Nitko dan Brookhart (2011: 497) menyatakan bahwa prestasi didefinisikan sebagai kompetensi yang dimiliki sebagai sebuah hasil belajar. Menurut Collins (20011: 4), prestasi belajar dapat didefinisikan sebagai hasil kompetensi, pengetahuan, serta tingkat capaian yang lebih tinggi sebagai cerminan hasil dari suatu value atau pengakuan dari publik. Johnson dan Johnson (2002: 8) mendefinisikan prestasi meliputi: (a) prestasi berhubungan erat dengan perilaku, (b) prestasi berhubungan erat dengan produk/hasil, atau (c) prestasi berhubungan erat dengan sikap dan disposisi/pengaturan.

Minat belajar pada diri siswa akan sangat mempengaruhi prestasi belajarnya (Koller, Baumert, dan Schnabel, 2001: 448). Minat merupakan pilihan terhadap suatu aktivitas tanpa ada paksaan dari luar dirinya (Nitko, 2007: 448). Jika perhatian terhadap pembelajaran tinggi maka kemungkinan hasil belajar juga tinggi. Minat belajar siswa terhadap matematika dijabarkan menjadi beberapa aspek yakni ketertarikan siswa dalam memilih aktivitas terbaik yakni dengan mengikuti pembelajaran matematika, memahami materi pembelajaran matematika, membaca buku matematika, melakukan interaksi bersama guru dan teman- 
temannya, merasa tertarik untuk belajar, memiliki interaksi yang aktif dengan guru dan teman, memperhatikan proses pembelajaran, memiliki rasa keingintahuan dalam proses pembelajaran di dalam kelas, serta mempelajari matematika dengan senang.

Prestasi belajar siswa merupakan tolok ukur keberhasilan suatu pelaksanaan pembelajaran. Siswa dengan minat belajar yang baik akan memiliki rasa senang pada saat belajar sehingga siswa dapat memperoleh hasil yang optimal dalam pembelajaran. Slameto (2012: 57) juga menegaskan bahwa sikap dan minat dalam pembelajaran berkontribusi besar pada hasil capaian belajar siswa. Model pembelajaran yang dipilih oleh guru dalam proses pembelajaran dianggap mampu meningkatkan minat siswa dalam belajar. Oleh karenanya pengaturan model pembelajaran pada situasi pembelajaran di masa pandemi Corona Virus Disease perlu mendapat perhatian khusus terutama oleh guru. Diantara model pembelajaran yang mampu memfasilitasi siswa dengan baik dalam pelaksanaan pembelajaran adalah model blended learning.

Blended learning menurut Moebs dan Weibelzahl merupakan model pembelajaran yang memadukan pembelajaran tatap muka dengan pembelajaran online (Husamah, 2014:12). Blended learning memberikan fleksibilitas tempat, waktu, serta pemilihan metode pembelajaran yang lebih bervariasi. Di dalam blended learning, selain mengandalkan materi yang diperoleh dari guru, siswa juga dapat mencari sendiri materi pembelajaran dengan berbagai cara, seperti mencari materi di perpustakaan digital, bertanya dengan teman sekelasnya, mencari materi pada website atau mencari tutorial pembelajaran dari search engine, portal, blog, maupun melalui media pembelajaran software lainnya.

Hasil penelitian Syarif (2012: 234) menunjukkan terdapat signifikansi peningkatan motivasi dan prestasi belajar setelah menerapkan blended learning dibandingkan dengan pembelajaran tatap muka. Blended learning berbantuan Google Classroom juga berhasil meningkatkan minat belajar siswa pada pembelajaran tentang konsep dasar Bahasa Indonesia dalam penelitian Inggriyani, dkk (2019: 28). Hasil penelitian Angraini, dkk (2018: 1) menunjukkan bahwa blended learning berbantuan Edmodo berhasil meningkatkan minat dan hasil belajar siswa. Dengan demikian implementasi model pembelajaran blended learning dengan subjek siswa kelas XI IPS 2 SMA Negeri 1 Bambanglipuro Semester Gasal Tahun Pelajaran 2020/2021 diharapkan menjadi alternatif perbaikan kualitas pembelajaran matematika di masa pandemi.

\section{Metode Penelitian}

Classroom action research ini terdiri dari dua siklus dengan tiap siklusnya memuat komponen planning, act, observing, dan reflecting. Subjek penelitian merupakan siswa kelas XI IPS 2 SMA Negeri 1 Bambanglipuro semester gasal 2020/2021 dengan jumlah 30 siswa, terdiri dari 18 siswa perempuan dan 12 siswa laki-laki dengan rentang waktu penelitian empat bulan dimulai sejak bulan Juli 2020. Pemilihan subjek didasarkan pada pertimbangan bahwa hasil observasi awal yang telah dilakukan kepada subjek menunjukkan terdapat permasalahan kurangnya minat belajar siswa sehingga berdampak pada rendahnya prestasi kelas tersebut. Penggunaan model pada penelitian ini dirancang supaya mampu meningkatkan minat dan prestasi belajar siswa. Sedangkan objek penelitian dari tindakan ini adalah proses pembelajaran menggunakan blended learning yakni pembelajaran yang mengkombinasikan pembelajaran online dan pembelajaran tatap muka dalam proses pembelajarannya.

Pengumpulan data pada penelitian ini diperoleh melalui tiga teknik, yakni angket, tes, dan observasi. Teknik angket dilakukan dengan tujuan untuk mengukur minat belajar siswa. Penyebaran angket kepada siswa diberikan sesudah pelaksanaan tindakan pada tiap siklusnya dengan menggunakan fasilitas google classroom.

Teknik pengumpulan data menggunakan tes bertujuan mengukur persentase ketercapaian indikator prestasi belajar siswa pada kelas tersebut, tes dilakukan di akhir pelaksanaan tindakan pada tiap siklusnya. Teknik pengumpulan data yang terakhir yakni teknik observasi pembelajaran bertujuan untuk mengetahui keterlibatan siswa dan tingkat keterlaksanaan sintak-sintak pada proses pembelajaran berlangsung. Hasil observasi dilaksanakan oleh satu guru kolaborator dengan dasar lembar observasi siswa dan guru.

Terdapat tiga instumen yang digunakan pada penelitian, yakni instrumen angket, instrumen tes, dan instrumen lembar observasi. Penyusunan instrumen angket minat belajar siswa bertumpu pada beberapa aspek didasarkan pada pendapat (Gable, 2003: 8), (Dai \& Sternberg, 2004: 94-95), (Nitko \& Brookhart, 2007: 448), (Elliot, et al., 2000: 345) yang dapat disimpulkan bahwa minat belajar siswa didasarkan pada empat aspek yakni perhatian, ketertarikan, keingintahuan dan pilihan. Dari 
Keempat aspek minat belajar kemudian dijabarkan menjadi 6 indikator dengan 13 butir angket positif dan 12 butir angket negatif dalam minat belajar siswa. Angket minat berbentuk checklist dengan menggunakan Likert skala 5. Instrumen tes belajar siswa berbentuk pilihan ganda dengan pertimbangan instrumen pilihan ganda memiliki beberapa kelebihan (Nitko \& Brookhart, 2011: 169).

Tes prestasi belajar siswa diberikan kepada siswa pada akhir siklus yakni setelah tindakan selesai diberikan. Sedangkan instrumen lembar observasi pada penelitian ini terdiri dua macam lembar observasi, yakni lembar observasi siswa dan guru. Instrumen lembar observasi guru mengukur keterlaksanaan langkah-langkah dalam proses pembelajaran pada model blended learning yang dilaksanakan oleh guru yang yang didasarkan pada sintak model pembelajaran blended learning menurut Grant Ramsay (2001: 25-27), yakni kegiatan pendahuluan, seeking of information, acquisition of information, synthesizing of knowledge dan kegiatan penutup pembelajaran. Sedangkan instrumen lembar observasi siswa diberikan bertujuan untuk mengetahui keterlibatan siswa dalam setiap kegiatan yang berlangsung. Pengisian lembar observasi siswa dan guru menjadi tanggung jawab guru kolaborator selama pembelajaran berlangsung pada tiap pertemuan dan setiap siklusnya.

Teknik analisis data yang diperguankan yakni analisis hasil angket minat, analisis hasil tes prestasi, dan analisis data observasi. Teknik analisis kualitatif angket minat menggunakan skala lima menurut Saifudin Azwar (2013:163). Semua butir angket dibagi ke dalam aspek sesuai yang diamati, langkah selanjutnya menghitung jumlah skor dari setiap butir pernyataan yang disesuaikan dengan pedoman penskoran. Jumlah perolehan dipersentase kemudian dikelompokkan sesuai dengan kualifikasi angket minat belajar siswa dalam pembelajaran matematika.

Analisa data hasil tes prestasi pada siklus I dan siklus II merupakan gambaran ketercapaian kompetensi siswa pada materi yang sedang dipelajari. Dari hasil analisis data tes prestasi kemudian disajikan dalam bentuk deskriptif. Perhitungan persentase skor tes prestasi adalah sebagai berikut:

$$
\text { Persentase }(P)=\frac{\text { jumlah siswa yang tuntas }}{\text { jumlah seluruh siswa }} \times 100 \%
$$

Pada penelitian ini hasil data observasi keterlaksanaan tahap-tahap pembelajaran yang diperoleh dihitung kemudian dipersentase. Hasil analisis dari data observasi pembelajaran kemudian disajikan dalam bentuk deskriptif. Perhitungan persentase skor tes prestasi belajar adalah sebagai berikut:

Persentase $(P)=\frac{\text { jumlah keterlaksanaan kegiatan }}{\text { jumlah seluruh kegiatan }} \times 100 \%$

Penelitian ini dianggap berhasil apabila indikator keberhasilan tindakan dapat terpenuhi, yakni: 1) apabila keterlaksanaan model pembelajaran blended learning oleh guru dan siswa berdasarkan hasil observasi mencapai 95\%; 2) apabila setiap hasil angket minat belajar siswa telah menunjukkan sekurang-kurangnya $75 \%$ siswa masuk kategori tinggi dan 25\% siswa lainnya dikategorikan sangat tinggi dalam kelas tersebut; 3) apabila siswa telah mencapai KKM dengan nilai sekurang-kurang 75 dan telah mencapai sekurang-kurangnya sebanyak $75 \%$ dari jumlah siswa di kelas tersebut.

\section{Hasil dan Pembahasan}

Sloan menjelaskan bahwa apabila 30-80\% aspek isi dan penyampaian pembelajaran dilakukan secara online maka pembelajaran tersebut telah dikatakan menggunakan model blended learning (Avgerinou, 2008: 1). Pada penelitian ini siklus I dan siklus II didesain dengan tiap pembelajaran dilaksanakan $70 \%$ secara online dan $30 \%$ secara tatap muka.

Pembelajaran tatap muka dilaksanakan pada saat kegiatan konsultasi pembelajaran sesuai jadwal sekolah setiap minggunya, dengan durasi pembelajaran tatap muka tidak lebih dari 30 menit. Pelaksanaan pembelajaran online meliputi komunikasi guru dengan siswa dalam grup whatsapp, penyampaian materi melalui video pembelajaran, e-module pembelajaran dan latihan soal menggunakan fasilitas Quizizz menggunakan fasilitas Google Classroom, serta diskusi kelompok kecil menggunakan video call grup whatsapp.

Pembelajaran online yang pertama dilaksanakan pada hari Rabu, 2 September 2020 dilanjutkan pelaksanaan 30\% pembelajaran tatap muka dengan durasi waktu 30 menit pada hari Kamis, 3 September 2020 dengan materi pengertian program linear dan pengertian sistem pertidaksamaan linear dua variabel. Hasil observasi keterlaksanaan blended learning pada siklus I dapat dilihat pada tabel 1. 
Tabel 1. Hasil Observasi Pembelajaran Siklus I

\begin{tabular}{|c|c|c|c|}
\hline $\begin{array}{l}\text { Siklus } \\
\text { I }\end{array}$ & Sintaks & $\begin{array}{l}\text { Kegiatan } \\
\text { Guru }\end{array}$ & $\begin{array}{c}\text { Kegiatan } \\
\text { Siswa }\end{array}$ \\
\hline \multirow{5}{*}{$\begin{array}{l}\text { Perte- } \\
\text { muan } \\
\text { I }\end{array}$} & Pendahuluan & $94,29 \%$ & $94,29 \%$ \\
\hline & Seeking of information & $80 \%$ & $65,00 \%$ \\
\hline & $\begin{array}{l}\text { Acquisition of } \\
\text { information }\end{array}$ & $80 \%$ & $80 \%$ \\
\hline & $\begin{array}{l}\text { Synthesizing of } \\
\text { knowledge }\end{array}$ & $86,67 \%$ & $80 \%$ \\
\hline & Penutup & $80 \%$ & $75,00 \%$ \\
\hline \multirow{4}{*}{$\begin{array}{l}\text { Perte- } \\
\text { muan } \\
\text { II }\end{array}$} & Pendahuluan & $97,71 \%$ & $97,71 \%$ \\
\hline & $\begin{array}{l}\text { Seeking of information } \\
\text { Acquisition of } \\
\text { information }\end{array}$ & $\begin{array}{l}80 \% \\
86,67 \%\end{array}$ & $\begin{array}{l}80 \% \\
86,67 \%\end{array}$ \\
\hline & $\begin{array}{l}\text { Synthesizing of } \\
\text { knowledge }\end{array}$ & $86,67 \%$ & $86,67 \%$ \\
\hline & Penutup & $80 \%$ & $80 \%$ \\
\hline \multicolumn{2}{|c|}{ Persentase Tiap Pertemuan } & $86,67 \%$ & $83,33 \%$ \\
\hline \multicolumn{2}{|c|}{ Persentase Siklus I } & \multicolumn{2}{|c|}{$85,00 \%$} \\
\hline
\end{tabular}

Berdasarkan hasil observasi pada siklus I di atas, tampak bahwa persentase keterlaksanaan pelaksanaan pembelajaran matematika dengan blended learning sebesar 85\% artinya belum memenuhi indikator keberhasilan. Dengan demikian perlunya tindakan perbaikan pada siklus II yakni dengan memaksimalkan diskusi online dalam kelompok kecil dengan menggunakan Voice Note dan Video Call Whatsapp. Hasil observasi keterlaksanaan pembelajaran pada siklus II dapat dilihat pada tabel 2.

Tabel 2. Hasil Observasi Pembelajaran Siklus II

\begin{tabular}{|c|c|c|c|}
\hline $\begin{array}{l}\text { Siklus } \\
\text { II }\end{array}$ & Sintaks & $\begin{array}{c}\text { Kegiatan } \\
\text { Guru }\end{array}$ & $\begin{array}{c}\text { Kegiatan } \\
\text { Siswa }\end{array}$ \\
\hline \multirow{5}{*}{$\begin{array}{l}\text { Perte- } \\
\text { muan } \\
\text { I }\end{array}$} & Pendahuluan & $97,14 \%$ & $100 \%$ \\
\hline & Seeking of information & $100 \%$ & $90,00 \%$ \\
\hline & $\begin{array}{l}\text { Acquisition of } \\
\text { information }\end{array}$ & $93,33 \%$ & $86,67 \%$ \\
\hline & $\begin{array}{l}\text { Synthesizing of } \\
\text { knowledge }\end{array}$ & $93,33 \%$ & $86,67 \%$ \\
\hline & Penutup & $95,00 \%$ & $95,00 \%$ \\
\hline \multirow{5}{*}{$\begin{array}{l}\text { Perte- } \\
\text { muan } \\
\text { II }\end{array}$} & Pendahuluan & $100 \%$ & $100 \%$ \\
\hline & Seeking of information & $90,00 \%$ & $100 \%$ \\
\hline & $\begin{array}{l}\text { Acquisition of } \\
\text { information }\end{array}$ & $93,33 \%$ & $93,33 \%$ \\
\hline & $\begin{array}{l}\text { Synthesizing of } \\
\text { knowledge }\end{array}$ & $93,33 \%$ & $93,33 \%$ \\
\hline & Penutup & $100 \%$ & $90,00 \%$ \\
\hline \multicolumn{2}{|c|}{ Persentase Tiap Pertemuan } & $96,19 \%$ & $97,14 \%$ \\
\hline \multicolumn{2}{|c|}{ Persentase Siklus I } & \multicolumn{2}{|c|}{$96,67 \%$} \\
\hline
\end{tabular}

Hasil observasi pembelajaran yang dilakukan pada siklus II diperoleh presentase keseluruhan keterlaksanaan model blended learning menunjukkan persentase sebesar 96,67\%. Dengan demikian dapat diperoleh kesimpulan bahwa tindakan pada siklus II telah mampu memenuhi indikator keberhasilan.

Selanjutnya menurut hasil penelitian Aditia Rachman, dkk (2019: 150-151) menunjukkan bahwa persentase ketertarikan siswa terhadap pembembelajaran dengan blended learning mencapai $78 \%$ yang tergolong pada tingkatan "menarik", siswa merasa senang dan menikmati proses pembelajaran dengan menggunakan blended learning, dengan meningkatnya hasil minat, motivasi, serta kesadaran belajar siswa. Menurut Slameto (2012: 180), minat adalah sebuah perasaan lebih menyukai dan lebih tertarik pada sesuatu atau aktivitas dengan sendirinya tanpa ada yang menyuruh.

Untuk mengetahui minat siswa, digunakan empat aspek yakni perhatian, ketertarikan, keingintahuan dan pilihan, maka pada penelitian ini diberikan angket minat siswa yang terdiri dari 25 butir pernyataan berbentuk checklist dengan menggunakan skala Likert. Semua butir angket dibagi ke dalam aspek sesuai yang diamati, langkah selanjutnya menghitung jumlah skor dari setiap butir pernyataan yang disesuaikan dengan pedoman penskoran.

Jumlah perolehan dipersentase kemudian dikelompokkan sesuai dengan kualifikasi angket minat belajar siswa dalam pembelajaran matematika. Selanjutnya dihitung nilai rata-rata ideal (M) dan standar deviasi ideal (S). Pengkategorian hasil skor angket minat didasarkan pada kategorisasi Azwar (2013: 163). Hasil penghitungan skor dan analisis angket minat belajar siswa pada siklus I dan siklus II dapat dilihat pada tabel 3 di bawah ini.

Tabel 3. Hasil Angket Minat Belajar Siswa

\begin{tabular}{lcll}
\hline \multicolumn{1}{c}{ Interval } & Kriteria & \multicolumn{1}{c}{ Siklus I } & \multicolumn{1}{c}{ Siklus II } \\
\hline $100<\mathrm{X}$ & Sangat & $20,00 \%$ & $33,33 \%$ \\
& Tinggi & & \\
$83<\mathrm{X} \leq 100$ & Tinggi & $53,33 \%$ & $66,67 \%$ \\
$67<\mathrm{X} \leq 83$ & Sedang & $26,70 \%$ & $0 \%$ \\
$50<\mathrm{X} \leq 67$ & Rendah & $0 \%$ & $0 \%$ \\
\hline Rata-rata & & $81,57 \%$ & $98,20 \%$ \\
\hline Kategori & & Tinggi & Tinggi \\
\hline
\end{tabular}


Peningkatan minat belajar siswa dengan model blended learning dari siklus I ke siklus II menunjukkan kenaikan persentase sebesar $85,00 \%$ pada siklus I menjadi $96,67 \%$ pada siklus II. Penelitian ini dianggap berhasil apabila setiap hasil angket minat belajar siswa telah menunjukkan sekurang-kurangnya $75 \%$ siswa masuk kategori tinggi dan 25\% siswa lainnya dikategorikan sangat tinggi dalam kelas tersebut. Dengan demikian diperoleh bahwa analisis angket minat pada siklus II telah memenuhi indikator keberhasilan.

Dari aspek prestasi belajar, hasil penelitian yang dilakukan oleh Tsaniyah, dkk (2019: 75) menyatakan bahwa pada populasi penelitian siswa MAN Baureno Bojonegoro dilihat dari kelas eksperimen dan kelas kontrol diperoleh bahwa rata-rata prestasi belajar pada kelompok siswa yang menggunakan blended learning (A1) lebih tinggi daripada yang kelompok siswa dengan pembelajaran konvensional (A2). Siti Banun dan Ninik Azizah (2013) dalam penelitiannya menunjukkan bahwa penerapan blended learning pada akhir siklus menunjukkan perolehan ketuntasan klasikal sebesar $92 \%$, dan sebanyak $72 \%$ mahasiswa masuk dalam kelompok minat yang tinggi. Penelitian ini menunjukkan bahwa blended learning berbantuan ICT mampu meningkatkan minat dan prestasi belajar mahasiswa.

Perolehan hasil tes prestasi belajar pada tiap siklus menunjukkan tingkat ketercapaian dan ketuntasan kompetensi siswa pada materi tertentu. Hal ini didukung oleh pendapat Tugan (2015: 99) bahwa prestasi akademik sebagai suatu pengetahuan tentang kemampuan dan tingkat kompetensi yang biasanya diukur dengan tes standar berdasarkan kinerja murid dalam proses pembelajaran. Grant dan Sleeter (2007: 30) juga menyatakan bahwa skor tes dapat digunakan sebagai indikator belajar siswa.

Selanjutnya Reynolds, Livingston, dan Willson (2010: 5) yang menjelaskan bahwa prestasi belajar ditentukan dengan jalan tes prestasi yang nantinya akan menilai kemampuan setiap individu sesuai dengan apa yang sudah dipelajari selama pembelajaran. Ebel dan Frisbie (1995: 19) juga menyebutkan bahwa tes prestasi belajar berkontribusi bagi keefektifan pembelajaran. Artinya tes prestasi belajar siswa berkorelasi dengan keefektifan proses pembelajaran yang telah dilakukan, sekaligus merupakan tujuan yang hendak dicapai dari sebuah kegiatan pembelajaran pada materi tertentu.
Tes pilihan ganda merupakan salah satu tes yang dapat dipergunakan dalam mengukur prestasi belajar (Miller, Linn, dan Gronlund, 2013: 202). Miller, dkk berpendapat bahwa untuk mengukur bermacam-macam tipe pengetahuan dan hasil belajar yang kompleks, tes pilihan ganda dianggap efektif untuk digunakan. Menurut Nitko dan Brookhart (2011: 169), kelebihan dari tes pilihan ganda adalah dapat digunakan sebagai penilaian target belajar daripada format tes lainnya. Selain itu, distraktor yang terdapat pada pilihan jawaban yang dipilih siswa dapat memberikan diagnosis terhadap kesulitan siswa dalam memahami materi pelajaran.

Instrumen tes prestasi pada penelitian ini merupakan tes tertulis berbentuk pilihan ganda yang dikembangkan dari kisi-kisi soal sesuai dengan kompetensi dasar. Berdasarkan hasil tes prestasi pada siklus I, diperoleh persentase siswa yang belum tuntas sebesar $67,67 \%$ dan siswa yang tuntas sebesar 33,33\%. Hasil tersebut menunjukkan bahwa tindakan pada siklus I ini belum berhasil. Dengan demikian perlu dilakukan refleksi agar hasil pada siklus II dapat menunjukan hasil yang lebih baik serta mampu mencapai indikator keberhasilan.

Tindakan perbaikan pada siklus II diantaranya dengan merubah susunan kelompok kecil agar lebih heterogen kemampuan tiap anggota kelompoknya, memaksimalkan diskusi online pada grup-grup kecil, memancing siswa untuk lebih aktif bertanya dan menyampaikan pendapatnya di dalam grup diskusi online baik dalam grup kelas maupun dalam grup-grup kecil, menyiapkan bahan belajar yang lebih terstruktur dan latihan-latihan soal yang interaktif seperti Quizzis serta memberikan penghargaan kepada siswa yang berani berpendapat dalam diskusi online dengan memberikan emoji, pujian verbal dalam bentuk chat ataupun Voice Note.

Analisis permasalahan-permasalahan pada siklus I dan tindakan refleksi yang dilakukan memberikan pengaruh yang signifikan pada hasil tes presasi belajar siklus II. Pada siklus II terjadi peningkatan yakni persentase siswa yang tuntas sebesar $76,67 \%$ dan siswa belum tuntas menjadi $23,33 \%$. Rata-rata kelas nilai prestasi belajar pada siklus II meningkat menjadi 79 . Berikut sajian kenaikan hasil tes prestasi dan jumlah siswa yang memperoleh ketuntasan belajar pada tiap siklusnya dapat dilihat pada tabel 4 berikut ini. 
Tabel 4. Hasil Tes Prestasi Belajar Siswa Siklus I dan Siklus II

\begin{tabular}{|c|c|c|c|c|c|c|}
\hline \multirow{3}{*}{$\begin{array}{l}\text { Komponen } \\
\text { Penilaian }\end{array}$} & \multirow{2}{*}{\multicolumn{3}{|c|}{$\begin{array}{c}\text { Siklus } 1 \\
\text { Tidak Tuntas }\end{array}$}} & \multirow{2}{*}{\multicolumn{2}{|c|}{$\begin{array}{r}\text { Siklus } 2 \\
\text { Tuntas }\end{array}$}} & \multirow{3}{*}{$\begin{array}{c}\text { Nilai } \\
\text { Rata-rata } \\
\text { Kelas } \\
\end{array}$} \\
\hline & & & & & & \\
\hline & $\begin{array}{c}\text { Nilai } \\
0 \\
\end{array}$ & $\begin{array}{c}\text { Nilai } \\
1,0-74,9\end{array}$ & $\%$ & Nilai $\geq 75$ & $\%$ & \\
\hline $\begin{array}{c}\text { Nilai Tes Prestasi } \\
\text { Belajar Siklus I }\end{array}$ & 0 & 20 & 67,67 & 10 & $33,33 \%$ & 67 \\
\hline $\begin{array}{l}\text { Nilai Tes Prestasi } \\
\text { Belajar Siklus II }\end{array}$ & 0 & 7 & $23,33 \%$ & 23 & $76,67 \%$ & 79 \\
\hline
\end{tabular}

\section{Simpulan dan Saran}

Berdasarkan data hasil penelitian dan pembahasan, maka dapat disimpulkan hasil penelitian menunjukkan bahwa 1) secara kuantitatif, peningkatan minat belajar siswa terlihat dari adanya peningkatan persentase minat belajar siswa dari siklus I yaitu sebesar $20,00 \%$ siswa memiliki minat sangat tinggi, $53,33 \%$ siswa memiliki minat tinggi, $26,70 \%$ siswa memiliki minat kategori sedang, pada siklus II persentase naik menjadi 33,33\% siswa memiliki minat sangat tinggi, 66,67\% siswa memiliki minat tinggi; 2) peningkatan prestasi belajar siswa terlihat dari persentase siklus I siswa yang belum tuntas sebesar $67,67 \%$ dan persentase siswa yang tuntas sebesar $33,33 \%$, pada siklus II meningkat yaitu siswa yang belum tuntas sebesar hanya $23,33 \%$ dan siswa yang tuntas menjadi $76,67 \%$. Karena telah memenuhi indikator keberhasilan penelitian yakni setiap siswa telah mencapai Kriteria Ketuntasan Minimal (KKM) dengan nilai sekurang-kurang 75 dan telah mencapai sekurang-kurangnya sebanyak $75 \%$ dari jumlah siswa di kelas tersebut, maka dapat disimpulkan bahwa prestasi belajar siswa dalam pembelajaran matematika pada materi Program Linear meningkat setelah menggunakan pembelajaran model blended learning; dan 3) Data observasi penerapan model pembelajaran model blended learning pada siklus I persentase keterlaksanaan pembelajaran model blended learning sebesar $85,00 \%$. Sedang pada siklus II persentase keterlaksanaan pembelajaran blended learning sebesar 96,67\%. Dengan demikian dapat disimpulkan bahwa hasil observasi pembelajaran model blended learning pada siklus II dinyatakan telah memenuhi indikator keberhasilan.

Dari hasil keseluruhan proses pelaksanaan blended learning mampu meningkatkan minat dan prestasi belajar siswa pada pembelajaran matematika. Untuk penelitian blended learning selanjutnya, peneliti lain dapat mengintegrasikan blended learning dengan model pembelajaran lain yang relevan dengan meneliti variabel lainnya seperti aspek kemandirian belajar siswa, motivasi belajar siswa ataupun aspek kognitif lainnya.

\section{Daftar Pustaka}

Angraini, M.R., Muharini, R., \& Lestari, I. (2018). Penerapan blended learning berbasis Edmodo terhadap minat dan hasil belajar siswa SMAN 9 Pontianak. Jurnal Pendidikan dan Pembelajararan Khatulistiwa, 7, 1-12.

Avgerinou, M.D. (2008). Blended collaborative learning for action research training. Journal of Open Education, 4(1), 88.

Azwar, Saifudin. (2013). Tes prestasi: fungsi dan pengembangan pengukuran prestasi belajar ( $\left.5^{\text {ed }} e d\right)$. Yogyakarta: Pustaka Pelajar.

Banun, S., \& Azizah, N. (2013). Penerapan metode blended learning berbasis ICT meningkatkan minat dan prestasi belajar pada mata kuliah ilmu sosial budaya dasar (ISBD) di prodi D-III kebidanan FIK UNIPDU Jombang. Jurnal Eduhealth. 3(2), 103-113.

Collins, J. W., \& O'brien, P W. (2011). The greenwood dictionary of education (2th edition). California: ABC-CLIO.

Dai, D. Y., \& Sternberg, R. J. (2004). Motivation, Emotion, and Cognition Integrative: Perspectives on Intellectual Functioning and Development. New Jersey: Lawrence Erlbaum Associates, Inc.

Dick, W., Carey, L., \& Carey, J. O. (2014). The systematics design of intruction, ( $8^{\text {th }}$ ed). Florida, FL: Foresmen.

Ebel, R.L., \& Frisbie, D.A. (1995). Mathematics in primary schools part I: childern and mathematics. London: Collins Educational Publisher Ltd.

Elliot, S. N., Kratochwill, R. T., Cook, L. J., et.al. (2000). Educational psychology: effective teaching, effective learning. New York: The Mc Graw-Hill Companies, Vol.1, No.1.

Gable, R. K., McCoach, D. B., \& Madura, J.P. (2013). Instrument development in affective domain: school and corporate application (3th edition). New York Sringer. 
Grant, C. A. \& Sleeter, C. E. (2011). Doing multicultural education for achievement and equity $2^{\text {nd }}$ edition. New York: Routledge.

Grant Ramsay. (2001). Teaching and learning with information and communication technology: Succees through a whole school approach. National Educational Computing Conference. Chicago: July 25-27.

Hudojo, Herman. (1988). Mengajar belajar matematika. Jakarta: P2LPTK.

Husamah. (2014). Pembelajaran bauran blended learning. Malang: Prestasi Pustakarya.

Inggriyani, F., Hamdani, A. R., \& Dahlan, T. (2019). Minat Belajar Mahasiswa dengan menggunakan blended learning melalui goole classroom pembelajaran konsep dasar Bahasa Indonesia SD. Jurnal Ilmu Pendidikan, Keguruan, dan Pembelajaran, 3(1), 28-35.

Johnson, D.W. \& Johnson, R.T. (2002). Meaningfull assessment: a Manageable and Cooperative process. Boston, MA: Allyn and Bacon.

Koller, O., Baumert, J., \& Schnabel, K. (2001). Does interest matter? The relationship between academic interest and achievement in mathematics. Journal for Research in Mathematics Education, 32(5), 448-470.

Miller, M.D., Linn, R. L., \& Gronlund, N. E. (2013). Measurement and assessment in teaching ( $11^{\text {th }}$ edition). Upper Saddle River, NJ: Pearson.

Mitchell, Mathew., \& Gilson, Judy. (1997). Interest and anxiety in mathematics. Chicago: Erick Clearinghouse.

NCTM. (2000). Principles and standards for school mathematics. Reston, VA: NCTM.

Nitko, A. J. (2007). Educational assessment of students. Englewood Cliffs, NJ: PrenticeHall, Inc.
Nitko, A. J., \& Brookhart, S. M. (2011). Educational assesment of students ( $6^{\text {th }} \mathrm{ed}$.). Boston, MA: Pearson Education, Inc.

Peraturan Menteri Pendidikan dan Kebudayaan. (2014). Peraturan Menteri Pendidikan dan Kebudayaan Republik Indonesia Nomor 59, Tahun 2014, tentang Kurikulum Sekolah Menengah Atas/Madrasah Aliyah. Jakarta: Kemendikbud.

Popham, W.J. (2011). Classroom assessment: What teachers need to know (6 $6^{\text {th }}$ edition). Boston: Pearson Education Inc.

Rachman, A., Sukrawan, Y., \& Rohendi, D. (2019). Penerapan blended learning dalam peningkatan hasil belajar menggambar objek 2 dimensi. Journal of Mecahnical Engineering Education, 6 (2): 145-152.

Reynolds, C. R., Livingston, R. B., \& Willson, V. (2010). Measurement and assessment in education. Upper Saddle River, NJ: Pearson.

Syarif, Izuddin. (2012). Pengaruh model blended learning terhadap motivasi dan prestasi belajar siswa SMK. Jurnal Pendidikan Vokasi, 2(2), 234-249.

Slameto. (2012). Belajar dan faktor-faktor yang mempengaruhi. Jakarta: PT Rineka Cipta.

Skemp, R. R. (1971). The psycholology of learning mathematics. Baltimore, MD: Richard Clay (The Causer Press) Ltd.

Suherman, dkk. (2011). Strategi pembelajaran matematika kontemporer. Bandung: JICA.

Tsaniyah, S. F., Ayu., H. D., \& Pratiwi, H. Y. (2019). Pengaruh model blended learning menggunakan scoology terhadap prestasi belajar ditinjau dari kemandirian belajar siswa. Jurnal Terapan Sains \& Teknologi, 1(1), 71-77.

Tugan, S. E. (2015). Relationship between test anxiety and academic achievement. Karaelmas Journal of Educational Sciences, 3, 98-106. 